culture and the culture of the future. Due to the mixture of technology and art in objects of Art \& Science, the society understands deeply the aspirations and movements of modern science.

\title{
References:
}

1. J.H. Falk. An Identity-Centered Approach to Understanding Museum Learning. Curator, 49 (2) (2006). pp. 151-166.

2. R. Kapurro. Informatsionnaya etika. Informatsionnoye obshchestvo [Information ethics. Information society]. \#5 (2010). pp. 6-15.

3. A. Liedts, I. de Buck. Technology as Context. Expand the scope contemporary artistic creations and traditional media by employing new technologies. LiedtsMeesen Foundation Publ., Ghent (2014).

DOI 10.15826/B978-5-7996-3081-2.51

\section{The Role of a Mediator in the Participatory Practices in the Museum (Mediation and Facilitated Discussion)}

\author{
Melnikova Svetlana' ${ }^{\text {, Zhuravleva Nadezhda }}{ }^{\text {, }}$ \\ Bulatova Anastasiya ${ }^{3}$ \\ 1 Ural Federal University, Ekaterinburg, Russia \\ 2 Ural Federal University, Ekaterinburg, Russia \\ ${ }^{3}$ Ural Federal University, Ekaterinburg, Russia \\ Corresponding author: Melnikova Svetlana, meln-svetlana@mail.ru
}

Abstract: In the era of the participation culture "viewer-inclusive" methods of communication in the museum have become in demand almost everywhere. The authors pose a question to the master of such a communication practices role. Analyzing participatory practices in terms of the achieved results, the authors appeal to the experience of art mediation (D. Malikova, E. Kochukhov, M. Lind, C. Mörsh), the VTC method (A. Housen, P. Yenawine) and its version adapted for Russian students - facilitated discussion (N. V. Ievleva, M. V. Potapova). The master of participatory practices acts as a part of an art environment. The master determines the perception and description norms for an art object, 
even if the traditional position of the teacher and expert is deliberately rejected. The development of creative thinking is the result of both methods. But if facilitated discussion primarily develops aesthetic literacy, then art mediation expands the museum communicative environment, attracting visitors from different demographic and psychographic groups and numerous communities.

Keywords: participatory practices, mediation, facilitated discussion, mediator, facilitator, art museum, aesthetic development, communication

\section{Introduction}

"New literacy" paradigm implies not only new communication languages and information formats, but also a change of the ways it is obtained. In a post-industrial society, each item has an economic meaning: it is important not only what is said, but also how it is said, how it is conveyed and interpreted, and consumers' interest of course. The old scenario of the simple "transfering" of authentic knowledge from teacher to student is not working today: "Traditional pedagogy, directed from the top down, does not contribute to the development of a thinking progressive society, which should ask questions, deeply explore problems and generate new relationships," S. Angiama notes [Manifesta workbook, 2014, 16]. According to A. Danto, modern art is a phenomenon which only the art professional community and relevant institutions can distinguish. We need mechanisms and technologies, as well as guides and institutions that ensure the functioning of art in modern culture.

Today, in art museums the roles of three traditional subjects-participants of art practices are changing. Firstly, the author ceases to be an autonomous founder of the meaning of the work. This was declared by M. Duchamp in the first half of the twentieth century. "It is the participation of the viewer that creates the picture" and "the artist did not create anything until the viewer said: “That's fine." The audience has the last word" [Duchamp, 2016]. "The works of a modern artist represent a fundamentally different "open" - type of work," says the esthetician E. Orel [Orel, 2017, 156]. This happens in the eternal process of "artist - viewer"dialogue, where the last word will be said by the viewer; also, it is caused in new forms of art: readymade, promotions, performance, plays, proms, street-art when viewers become participants of the art work. Secondly, the role of the Museum worker-" the guide" (teacher) is now perceived as "passive" by both guides and tourists. This model is inconvenient for viewers who are accused of ignorance, but it also became not suitable the expert, who strives for activity, and much more 
sympathetic to the role of an "illiterate teacher" [Rancier, 2018] than a "keeper of values". Thirdly, the viewer (student) also strives for action, and the "culture of the recipient" is forming in museums [Weibel, 2012]. "Contemporary art presupposes the active participation of the viewer in the artistic process", declared in Manifesto 10 [Manifesta 10, 2014]. The research of Museum auditories "21st Century Skills" made by the American Institute of Museum and library services (IMLS), highlights the stimulation of critical thinking, creativity, communication skills, the ability to partner, cooperate and produce new meanings, interdisciplinary and cross-cultural thinking, visual literacy, and, among other things, working with media resources [Museums, Libraries, and 21st Century Skills: Definitions]. Fourthly, the museum environment is changing and more and more specimens are becoming digital. Media art theorist Peter Weibel writes: "And if over the next decades we can't adapt to the new behaviors learned by online viewers, the museum's function will become outdated, as the viewer will say: "I only go to a Museum when I want to experience the old-fashioned cultural behaviors. When I want to experience a modern model of cultural behavior, I won't go to a museum, because if it throws me back to the XIX and XX centuries." So, in my opinion, museums must adopt a new way of doing things" [Weibel, 2012].

What is the role of a mediator accompanying visitors in the museum? What may the mediator change in the perception of art? What should the mediator inspire the viewer to be active, to extract information from what he saw, make independent judgments and get satisfaction from mental work?

There are many scenarios of participatory museum practices, so it makes sense to analyze the difference between existing practices. The difference will be located in the "goal-result" field and directly depend on the behavior of the mediator (the guide).

\section{Methodology}

The development of the museum participation culture makes participatory practices more and more popular. The main thing that changes participatory practices is the transition of the museum (exhibition) paradigm from the "Keeper of values" format to the communicative one. Analyzing the specifics of participatory museum practices, we rely on the one hand on philosophical studies of the aesthetic perception, on the other on the experience of applying new methods and their understanding in the framework of Museum education. 
Sociological analysis of the aesthetic theory, proposed by P. Bourdieu, allows us to understand several important points. Firstly, art museum is an institution that allows, through specialized agents (guides), to impose on the viewer the norm of seeing a work of art. Secondly, this vision is conditioned by the language of art description. Thirdly, the form of interaction between the art object and the viewer, mediated by the museum, has a historical conditionality.

Rejecting "essentialist thinking", Bourdieu suggests replacing the ontological question with a historical one and analyzing the aft environment formation. "We should analyze the emergence of specific institutions, influencing economy of cultural goods" [Bourdieu, 2003, 23]. He refers to specialized agents who possess the specific knowledge of art perception and evaluation and are able to "impose a specific way of measuring the value of the artist and his products." They are critics, art historians, and collectors who determine the norms of vision and description of an art object. The perception of art needs the help of a language that can express what we see and at the same time force our eyes to see in a certain way.

"One of the most important is undoubtedly the creation of an artistic language. First of all, this is a way of naming the artist, to talk about him, about the nature and value of his work (not only financial). At the same time, art language is a way to talk about painting itself and painting technique, using special words, often pairs of adjectives that allow us to talk about art (manifattura) and even about the special manner of the artist" [Bourdieu, $2003,23]$. The categories of artistic language differ from words used in everyday speech. The art discourse allows numerous agents, including the author, to produce "objects recognized as artistic". For a visitor of an art museum who does not know the tools of perception and evaluation, the language of art description and does not know all that Bourdieu calls labels and codes, a work of art has not any meaning and value. "The aesthetic view constitutes a work of art as such" - he says [19-20], on the other hand, the aesthetic view itself is a product of training.

We can conclude that the museum is not only a place for displaying art, but also a place that forms the consumer of art. And, as we assume, the appearance of modern museum practices is the result of the functioning of a whole complex of dependent elements.

One of these elements is a change in the social demand for the goals and objectives of museum activities, which are not limited only to the display 
of art collections. This is clearly seen in modern works devoted to the problem of aesthetic perception.

Jacques Rancier sees the attitude of power in the professional aesthetic discourse - a strategy of keeping dumb. That's why he demands the viewer's independence from the mediators (teachers) who impose "only true" knowledge. Although Rancier is speaking about the theater, it is obvious that his ideas can be transmitted to the visual arts in general: "Emancipation begins when the opposition between view and action raises questions in our mind. It begins when we understand that the wathing is also an action that accepts or transforms a given distribution of positions. The viewer also acts as a student or scientist. The viewer observes, selects, compares, interprets" [Rancier, 2018, 16].

The "ignorant teacher" and the "independent student" are complementary, equal subjects of aesthetic perception, and their views equally constitute and enrich an art object. Rancier rejects the fact that the mediator (teacher) and the viewer (student) are having identical views of the work, artistic intent and perception. Truth, if it exists, is somewhere between the teacher and the student, the artist and the spectator. "The logic of the emancipation assumes that in addition to the ignorant teacher and the independent student, there is always a third thing - a book or a fragment of text that has nothing to do with either. This is the third thing that the student and the teacher can turn to in order to jointly verify what the student saw, what he says about it, and what he thinks" [Rancier, 2018, 18]. Any art object is a third thing that acquires the postmodern characteristics of a text, which is open to endless interpretations. The rejection of traditional discourse may be dictated by the belief that not only the mediator, but also the art work itself, should not be considered as a translator of the author's idea and depend on professional criticism proving its aesthetic status. Independence of the viewer implies a different way of art perception. Perception, for which all opinions are equal and depend on personal experience. "Being a spectator is our normal situation. When we study and teach, act and learn, we are the same viewers who every second connect the visible with all the things we have already seen, said, done and imagined" [Rancier, 2018, 20].

In that way, the educational attitude (to reveal the author's intention), formulated in the Soviet tradition by the question "What did the artist want to tell us?", has now changed into the new question: "What do we see?". M. Lind notices that this question "often collides with the modernist idea of art, which 
is not imposed on the viewer, but (should be) self-sufficient so that it can "speak for itself", outside of "external" contexts. Which leads to a pedagogy devoid of context - "what you see and what you feel"'" [Lind, 2018]. The appeal to the viewer, in this case, is devoid of the appeal characteristic of modernism to connoisseurs, whose aesthetic sensitivity is due to artistic literacy. For J. Ortega y Gasset the language of art - the condition and the consequence of artistic susceptibility, allows you to separate the spiritual aristocracy from the masses. The basic principle of Ortega y Gasset's philosophy, which claims for the anti-egalitarian status of authentic art, is a specific vision and description norms. "New art divides the public into two classes - those who understand and those who do not understand the art — artists and those who are not artists" [p. 236]. Being an artist for Ortega is, among other things, the ability to see the artistic. This is ability of the small number of experts, critics, sophisticated viewers, who are opposed to the power of the ignorant masses. The reverse side of the processes of democratization, that terrified him, was the widespread belief that the art can transform the viewer's consciousness and expand it by a "true" experience of aesthetic vision, approved by specialists. An artistic discourse remains under the power of the expert who owns the truth, and the student's view is ignorant. But taking the position of Rancier, we must remember that the viewer should not see exactly what the artist wanted to express, or what the teacher wants to put into it. Equalizing the positions of all participants in communication - the viewer acting as a student and a teacher, the artist and the work generates freedom of interpretation - offers freedom of view and expression.

In the 1960s A. Danto used an analytical method to study art, its language and boundaries. The scientist discovered the "world" of art and interpreted it as a holistic phenomenon that could no be longer perceived in a linear paradigm. The artist sees something, not as existing in reality, but as existing for himself. For the viewer, this vision, even interpreted by the artist, is not obvious, and never fully coincides with the artist's vision. The viewer reassembles the work based on his own preferences and judgments. It makes us understand that art is neither a pure abstraction, nor also the part of everyday life, all those real things. He noted: “... this case is almost sociological” [Danto, 1964, 584]. In English language," to see "means not only the action of the organ of vision, but also watching, that is, when the verb means not only to see, but also to understand. This means a fact that usually happens to us: before we see something, we are already influenced by it, we are always 
under the influence of previously accepted, traditional things. As a result, all we can do with this is to reassemble it, in accordance with our own preferences, insofar as tradition allows us to do this, because it always strives to be interpreted, translated, even distorted, but still transmitted [Duv, 2014]. By reassembling tradition and imbuing it with our own feelings, each of us creates a new reality, just as art creates its 'own world'. The name and display of showpieces, the entire space of the museum guide the viewer to a certain understanding of the work - based on this principle that A. Barr built exhibitions. But the viewer does not even realize it.

According to A. Huysen, postmodernism affected the status of the museum and its functions, "the understanding of the role of the museum as a place of elite preservation of culture was replaced by the perception of it as a place of mass communication with spectacular mise-en-scène (spectacular miseen-scène) and opera excesses" [Huysen, 2012]. In an effort to attract the audience, museums are forced to abandon traditional didactics and look for new forms of interaction with the audience, becoming a place of family leisure, entertainment and communication. "New Museum and exhibition practices meet the changing expectations of the audience. An increasing number of viewers are looking for strong feelings, instant revelations, grandiose exhibitions rather than serious and thorough development of cultural knowledge" [Huysen, 2012]. This is also true for the art museum and artspace. Participatory practices appeared due to the necessity to attract both sophisticated art lovers and newcomers who do not have the skills of aesthetic perception nor tools for evaluating and analyzing a work of art.

\section{Applying the methodology in Museum education}

Today, dozens of communication options are described in various exhibition and educational spaces [Simon, 2017; True needs. True partners: Museums and schools Transforming education, 1996]: this is personalization of visits, network presentations (Anne Frank Museum), "Internet arm wrestling", "live library", "Postsecret", development of co-creation platforms, network projects, mediation, VTS, joint school-museum projects that change educational scenarios. Diane B. Frankel, Director of the Institute of Museum Services gathered 15 active projects of collaboration of schools and museums and various forms of mediation. A large study of 9 chapters and 329 pages," Time for cultural Mediation", conducted by the Swiss Foundation Pro Helvetia in 2009-2012 and presented in German, French, Italian and English [Time 
for Cultural Mediation, 2013], is devoted to cultural mediation, its various forms, among which mediation in the art museum is the leading, but not the only one. The most important function of the museum is "the function to provide space for cultural practices derived from both elite circles of art appreciation and populist strategies for audience development" [Time for Cultural Mediation, 2013, 33].

Maria Lind, a contemporary art theorist and curator, in an article on art mediation, identifies three main museum approaches to working with visitors that were observed throughout the twentieth century: the traditional didactic approach aimed at creating an "enlightened consumer", the supporter of which she calls Alfred Barr, founder and Director Of the New York Museum of Modern art (MOMA); the approach that puts at the forefront the "participant" visitor, his personality and creativity the "collective spectatorship". The approach insists on the need for joint, collective meetings with art, involving the viewer in the process of perception and evaluation of works in their own way, so they can be called participatory. All these approaches have a common goal - to connect art and the viewer. They all are forms of mediation, "interaction of art, institutions and the outside world" [Lind, 2018] but they also achieve different goals, aimed at work with different types of users, and possibly with different objects. As for the objects, let's clarify that if we talk about art exhibitions, completely different methods of audience engagement will work with "traditional" art and unusual for most viewers, sometimes strange and shocking works of modern art.

The first approach can be called the most popular in museums which identify themselves as educational centers. D. Joslit, calling museums "quasi-universities", "encyclopedias of art works", evaluates the museum as a project of modernist art producing the visual knowledge [Joslit, 2017]. Museum directors and curators form the exhibition space and accompany the exhibition (excursions) based on the goal of improving the literacy of the audience. Collected and described by, for example, Diane B. Frankel by Diana Frankel projects of close cooperation of schools not only with different museums, when teachers and researchers of museums work successfully together, increasing the effectiveness of lessons and the regular school curriculum, just demonstrate the advantages of this approach. Diane B. Frankel insists that museums and schools together are the most effective way to teach children.

We will interpret the second and third approaches in relation to practices that are actively developing in our country. Lind says that in 1937 MoMA 
established an independent educational department under the leadership of Victor D'amico, which began to promote visitor participation: "instead of focusing on pleasure or judging art, the educational department encouraged viewers to explore their own creativity." This approach turns out to be surprisingly modern today: the viewer comes to the museum not to "pour" information into the brain, but to develop it, activate the ability to observe, select, and systematize. These properties are necessary for a modern schoolchild, a student. The old approach is usually in demand by older generations of visitors, but being passive learners is boring for young people. Museums need special people - mediators whose task is not to "retell" and "convey", but to "connect" and "attract attention" or "get a response". This common task is embodied in various mmethods that focus on certain processes of interaction between the museum and visitors.

The third, "collectivist" approach, which grew up on the ideology of constructivism (according to. Lind) in addition to democratic skills (very important!) it also provides an opportunity for communication in the group, when the audience that has a certain training in the field of art perception can ("brainstorming") increase the degree of this training, along with the ability to express an opinion to each member of the group. This gives museums a chance to play the role of "third place". Nina Simon, describing various museum projects, highlights the fact that visitors begin to feel involved, solving a certain problem together, continue to maintain relationships through social networks, find new friends, and there are examples of joint responsibility, etc.

Ural industrial Biennale creator Daria Malikova says: "If the classical museum is focused on the presentation of collections, and makes decisions based on what it can show to visitors, then the new generation museum is a platform for bidirectional communication, putting involvement and exchange at the forefront" [Malikova, 2015, 24]. Individual museum projects contribute to the formation of stable communities. Here, as in the previous approach, you need a mediator, a specialist who can competently guide the group discussion not so much to the "desired result", but to bring it to some general opinions, generalizations, unite people, and so forth.

We would call the second and third approaches close to art mediation. It is also seen in another practice, VTS, Visual Thinking Strategies, which is presented in a special version, a facilitated discussion in our country, in the Russian Museum. 


\section{Practical part}

\subsection{Mediation}

The term "kulturvermittlung'"' cultural mediation, came into museum use in the first decade of the 2000s. In 2013, the Zurich University of the arts published study “ Time for Cultural Mediation”, conducted by the Swiss Foundation Pro Helvetia in 2009-2012. K. Mersch, notes the semantic richness of the concept of "mediation", which is not reducible only to artistic programs: "despite the limited functions of this program, there is a huge variety of approaches and ways to develop problems and issues related to cultural mediation, which makes them applicable to other parameters and activities in which cultural mediation takes place" Time for cultural mediation, 2013, 15]. Mersch defines mediation as follows: "the term cultural mediation, translated here from the German term "kulturvermittlung" and the French term "médiationculturelle", although quite open, usually refers to the process of obtaining and discussing knowledge about art and social or scientific phenomena through exchange, reaction and creative response" [Time for Cultural mediation, 2013, 17]. Moreover, Mersh distinguishes the situation of cultural mediation from Museum pedagogy. The new term, mediation, is related not so much to education as to work in the arts, various cultural and social fields: "where 'education 'or 'teacher' most often means participation in the formal education sector, the term cultural mediation also allows practitioners to present themselves as part of a wider range of cultural workers in various artistic disciplines working in various cultural and social fields".

In 2014 St. Petersburg hosted the Manifesta 10 European Biennale, an event that used cultural mediation as its mandatory component. It brought a new phenomenon to the national museum practice, and methodically clarified its application. Manifesta said that the term "mediation" is widely used in Europe in the context of galleries, museums and contemporary art and is an example of gallery or museum education for the general public. Mediators are "literally mediators between the curator's own vision and the visitors' perception, which is formed during a joint walk around the exhibition. Art mediation provokes intellectual and sensual communication with artists " works, exchange of opinions, and leaves space for an emotional experience of art. Ordinary human reactions are unavoidable, allowing them to manifest is the best thing a guide, mediator, or guide can do before adding facts from the author's biography and textbooks on aesthetics" [Manifesta 10. European Biennale of contemporary art, 2014]. Thus, a mediator is a person who does 
not give his own assessment of works of art, but participates in the process of forming it in the viewer. The role of the mediator is to facilitate dialogue and knowledge sharing.

D. N. Malikova, curator of Ural industrial Biennale mediation projects since 2015, is a developer of mediation practice in the Urals and sees three parties as mandatory components of a mediator's activity: a translator, a mediator, and a guide [Malikova, 2019]. "In a comprehensive sense, we define mediation as a function of transferring and sharing knowledge in the field of art, implemented with a new understanding of the museum's mission as an cultural dialogue curator" [Malikova, 2015, 43]. The researcher 4th Ural industrial Biennale E.S. Kochukhova notes that the mediation project at the Biennale "is one of the first steps towards a new museum communication. The advantages of this project are positive feedback from the audience, as well as relevant examples for further research confirming that museum practices are really undergoing transformation" [Kochukhova, 2019, 268].

Lind understands mediation as a "dating service" that helps to establish the contact between the people and things. Mediation "is dedicated to creating contact surfaces between people, works of art, and curatorial projects; it establishes various forms and adjusts the intensity of communication around and about art" [Lind, 2018]. The term "mediation" has now become a broad concept that combines meanings from psychosocial mediation to techniques of art history analysis. Each exhibition institution uses "mediation" with its own understanding. Art mediation that accompanies contemporary art exhibitions has its own characteristics.

The authors of this article have previously noted that mediation radically changes not only the status and purpose of the guide figure in a modern Museum. The mediator changes the very principle of communication between an exhibition site employee and the audience [Bulatova, Zhuravleva, Melnikova, 2019]. The task of the mediator is to ask questions and encourage the viewer to observe their reactions who no longer expects to get a readymade explanation, he understands that the meaning comes from within. The mediator, as a conductor of communication, focuses on viewers, on their feelings and experiences. It becomes obvious to the viewer that a lot depends on their reactions and their position. Not being an "expert", the mediator becomes a "trigger", he has the right to make mistakes and express dubious interpretations, thereby arousing the viewer's protest or support, his interest in finding his own pro and contra arguments. All this leads to the eman- 
cipation of the viewer, who becomes an active participant in the process of understanding the work finding real psychological contact with it.

\subsection{Facilitated discussion}

Facilitated (free) discussion is another method of communicating with the audience in the museum, which was developed by N.V. Ievleva and M.V. Potapova in relation to the audience of senior schoolchildren and students [Ievleva, 2018] in the early 2000s. The method is based on the use of VTS, a Visual Thinking Strategy that was created and has been practiced by A. Housen and P. Yenawine since 1993 [Housen, 2001-2002; Visual Thinking Strategies].

The essence of the VTS method is group work on an art work (suitable and specially selected for this session). The group includes 5-10 students and a teacher leading the conversation. Students are asked questions that help them carefully examine the work. Questions are always open, the moderator uses a paraphrase, repeating the answers of students, and, at certain intervals, summarizes the answers in a group result [Housen, 2001-2002, 106]. Open questions are strictly worked out, they direct the viewer to the material of the picture: "What do you see here?", "What allows you to talk about it like that?" [Working with the student audience in the art museum using the method of free (facilitated) discussion, 2016]. Hausen and Yenavine, together with a team of teachers, have been teaching students the perception of art for 30 years, which has a positive impact not only on the aesthetic, but also on the overall personal development of students. Research on the application of the method has shown that students form critical thinking, acquire the skills to openly and argumentatively judge what is happening, and, of course, increase their aesthetic development.

A. Hausen, using the method of aesthetic interviewing visitors to the New York Contemporary Art museum, discovered five stages of aesthetic development: the first stage is the stage of the narrator - "accountive" (the viewer sees only the concrete and obvious, the perception is extremely egocentric, the picture is evaluated at the level of "like - dislike"); the second stage is "constructive" (the viewer demands photographic accuracy and realism from the picture, if he does not get it, he can distance himself from the work of art; at this stage the viewer can rely on their own perception, their knowledge of the natural world and social, cultural, moral values); the third stage is the "classifying" (the quality of the picture is determined by the author's name or affiliation to a particular style or direction in art, the viewer is relying on its own knowledge wants to rationalize the meaning of works of art by finding 
him a place in the history of art); the fourth stage - "interpretive" (intuitive perception of the viewer, his personal opinion, in order to reveal the symbols and meanings that can change with each new encounter with the work, so viewers see and own the processes and changes); the fifth stage is "recreational" (it involves analyzing the picture from different points of view, finding a lot of contradictory meanings in it, the audience combines personal ideas with universal ones). As a result of the experiment, five years of work with schoolchildren using the VTS method, the majority of students rose from the 1 st to the $3 \mathrm{rd}-4$ th stage, three times ahead of the control group [Housen, 2001-2002, 112-115].

The method was used in our country in school education (the program "Image and thought"), and today it is presented in the Russian Museum, thanks to the activity of the Department of social and psychological research. The principle of applying the VTS method in both programs is similar.

The authors of the program "Image and thought" (which was developed for preschoolers and primary school children in the early 1990s) L. M. Vanyushkin and L. Y. Kopylov based their ideas the works of psychologists L. S. Vygotsky, J. Piaget, and others. According to the authors of the program "Image and thought", their task is to develop visual thinking, understood "as the ability to see the semantic essence of the visual image of a work: organized pictorial surface, a combination of sculptural forms; the ability to capture the mood of color spots or lines, to understand the meaning of building space on a two-dimensional plane, to understand the meaning of the interaction of light and shadow, texture, that is, all that is commonly called figurative means of fine art" [Museum and school in educational space, 1997, 66-67]. The development of visual perception strategies is achieved through sequential "entry" into works of art. To do this, this educational technology uses a sequence of questions and the principle of organizing a facilitated discussion. A special role is assigned to the teacher-facilitator. The task of the teacher was to maintain the discussion, the ability to listen and hear.

The method of free (facilitated) discussion has been used in the Russian Museum since 2012. Currently, 6 city schools and 5 technical universities participate in the program [Ievleva, 2018]. Classes are held on the basis of a museum exhibition (suitable and relevant works) with groups (12-15 people), where participants are given the freedom to express themselves based on their own impressions and assessments. The museum employee who conducts such a discussion does not give participants any information 
(about the work, author, etc.) and does not evaluate the thoughts and opinions expressed. Its role is to maintain an active discussion in the group [Ievleva, 2018]. In the process of discussion, it is necessary to concentrate the viewer on the work of art, make them carefully examine the image, see it as a whole and with all the details, concentrate, hold and switch their attention. N. V. Ievleva and M. V. Potapova note that the possibility of using free discussion to get acquainted with art is due to the main characteristic of art - polysemy, which allows for different and equal points of view on the work. The purpose of the meeting for all participants is to understand the essence of the work, using the language of fine art [Working with the student audience in the art museum using the method of free (facilitated) discussion, 2016].

\subsection{Comparison}

The techniques of art mediation and facilitated discussion have common sides, both methods move away from formal training, from the stereotype of transmitting ready-made knowledge. As a result, the distance between the expert and the viewer is reduced, the barrier (the status of "ignoramus", "dilettante") is removed psychologically. Each person is competent in several areas, but is an amateur in all others, so the communication of people from different areas enriches all aspects of communication [Kochukhova, 2019]. Authors define the common features of mediation and facilitation:

- treating the visitor as an equal, having their own vision and perception of art;

- engaging the viewer in communication, encouraging them to speak, and pronouncing what the viewer sees (translating from "visual" to "verbal" language);

- "radial thinking": the starting point is the work, but the result of the conversation depends on the group participants;

- noticing the details of the work, not just a complex look;

- stimulating co-creation in the process of revealing the meaning of the work, increasing the creativity of both sides of communication;

- attention to the individual needs of the visitor, interacting with the meaning of the work with the current problems of the viewer.

The result of these methods addressed to the viewer is not so much ready-made new knowledge, but the ability to find the path that the student will have to go himself. This approach, according to D. N. Malikova, corresponds to the socio-constructivist approach in education, which is characterized by the dependence of the learning result on the meanings introduced 
by students, collective goal setting, and blurred evaluation criteria. In this case, "the role of the teacher is reduced to the role of a guide, moderator, who forms the learning environment in order to make it the more effective" [Malikova, 2019, 13].

However, mediation and facilitated discussion are different practices. This difference lies first in the role of the mediator, the subject leading the communication. Secondly, in the process of communication and in the results of this communication.

Intermediary. The authors conducted a small survey of mediators of Ural industrial Biennale-5. Some statements are based on this survey and some on the author's (a member of this team) experience.

- The moderator of a facilitated discussion is always an expert, he has an excellent understanding of the material, and he has a special professional education. An art mediator, in comparison, may not be an expert or have special knowledge. The experience of conducting art mediation (Ural industrial Biennale, Manifesta) has shown that the task of mediation is perfectly handled by people of various professions, not experts in the field of art, who have never led excursions. Among the art mediators, there are not so many professional art historians (in the team of art mediators of Ural industrial Biennale -5 , where one of the authors of the article worked, only 3 out of 33 people had a degree in art history, two were art students). Among the 15 mediators who passed the survey, $54 \%$ had a liberal arts education. The remaining 46 do not work in the art sphere. Thus, the mediator and the viewer are colleagues, they talk "on equal terms".

- The facilitator's activity directs the viewer to a careful consideration of the work. His opinion remains with him. The facilitator does not allow himself to ask such questions as "what do you think about it?", "what do you feel?", his task is to concentrate only on the art work to teach viewers to notice and read. The mediator shares his own impressions with the audience, encouraging them to engage in a dialogue. The subject of the dialogue may not be a separate work, but the curatorial idea, the theme of the exhibition, etc.

- The facilitator is always operating with special questions, according to a well-developed scheme in context to the art work. Questions like "what do you think about it?", "how do you feel" are prohibited because they lead away from the art work analysis. "A mediator is a person who is between two parties, without joining any of them and without making any judgments about them. Its role is to promote dialogue and knowledge sharing" [Workbook. 
Manifesta, 2014, 16]. The viewer's thoughts and associations often lead them away from the language of a particular work and into a broader cultural field.

- The facilitator, working professionally with aesthetically untrained viewers, develops their ability to judge. The mediator, being almost equal to the viewer, can take something from each mediation session for his development. According to the results of our survey, $37 \%$ of mediators have a better understanding of art, while $29 \%$ noted that they have improved their communication skills, and $14.5 \%$ have gained new knowledge.

\section{The process:}

- the goal for both methods is to uncover the activity and personal perception of the viewer. But if mediation is aimed at attracting the audience's attention to a particular exhibition and participation in it, or even just for the "cultural entertainment" of the visitor, then a facilitated discussion is always tied only to a work of art, its goal is to give an opportunity to "read' elements of the artistic language, to teach concentration, to understand the essence of the work.

- focus of activity: in mediation, the activity of "participation": the viewer is connected to participate in the discussion of the exhibition and the work. In a facilitated discussion, the activity is aimed at carefully investigating the work.

- the direction of the conversation: in mediation - to go from the audience, from their questions, based on their experience and understanding. The mediator's behavior is situational and depends on the group. In a facilitated discussion, the direction is only from the work, it is important to go from the material, to direct questions to the material. The facilitated discussion follows a clear plan.

- direction of thinking: in mediation, "Their thoughts should cover all areas and levels.” [Workbook.Manifesta, 2014]. In a facilitated discussion, all thoughts are directed at understanding the language of the work.

- the task of mediation can be described by the words "look and think", and facilitated discussion - "look and see". Mediation is organic to contemporary art exhibitions, and the facilitated discussion tends towards the classical museum.

The results. The mediator provides interest in a particular exhibition or museum, people want to get to it, bring friends and connect to the community event. The result of the mediator's work is free communication in the museum space. The result of a facilitated discussion is an aesthetic 
development which is implemented in an interest in art and the ability to read artistic language.

\section{Conclusion}

In open methods we see a familiar postmodern paradigm that changes the focus from the art work to numerous interpretations. This "active interpretation" (the term of J. Derrida), free from author's and expert opinions, arises in the process of museum discussion practices.

Aesthetic perception is the result of a complex communication process involving equal participants: the author, the art work, the curator, the audience, and intermediaries. Today, not only individual artistic texts are beginning to have a semantic value, but also curatorial ideas embodied in utterances inspired by the various works of art. An inexperienced visitor of art galleries needs to "tune in" to become a full-fledged participant in such an event. The guide in this case is an art mediator, but you can "read" a separate work, thanks to the skill acquired during a facilitated discussion.

The freedom of interpretation claimed by postmodernists becomes not an elite intellectual amusement, but an accessible way of communicating with art.

\section{Conflict of Interest}

The authors have no conflict of interest to declare.

\section{References:}

1. Rabochaya tetrad'. Manifesta. [The Workbook. Manifesta] (2014). URL: http:// manifesta10.org/media/uploads/files/workbook_mediation_rus.pdf (Accessed 31 August 2020)

2. M. Dyushan. "Obo vsem" Marselya Dyushana [Duchamp M. "about everything" by Marcel Duchamp] URL: https://batenka.ru/explore/field/marcel-duchamp/02avgusta2016g. (Accessed 31 August 2020)

3. E. V. Orel. Iskusstvo pod sledstviyem: amerikanskiy i rossiyskiy opyt [Art under investigation: American and Russian experience]. Khudozhestvennaya spetsifika i sotsial'nyy potentsial sovremennogo iskusstva: sb. nauch. st. [Art specifics and social potential of modern art: collection of scientific articles] Gumanitarnyy universitet [University of humanities]. Ekaterinburg (2017), pp. 148-185.

4. ZH. Rans'yer. Emansipirovannyy zritel' [The emancipated spectator]. Krasnaya lastochka, Nizhniy Novgorod (2018). 
5. P. Weibel. Muzey 2.0. Iskusstvo [Museum 2.0. Art.]. № 2 (581), Moscow (2012). URL: http://iskusstvo-info.ru/muzej-2-0/ (Accessed 31 August 2020)

6. Manifesta 10. Yevropeyskaya biyennale sovremennogo iskusstva. [European Biennale of contemporary art] (2014). URL: http://m10.manifesta.org/ru/education/ art-mediation/ (Accessed 31 August 2020)

7. Museums, Libraries, and 21st Century Skills: Definitions. URL: https://www. imls.gov/issues/national-initiatives/museums-libraries-and-21st-century-skills/ definitions (Accessed 31 August 2020)

8. P. Burd'ye. Istoricheskiy genezis chistoy estetiki: Essentsialistskiy analiz i illyuziya absolyutnogo [Historical Genesis of pure aesthetics: Essentialist analysis and the illusion of the absolut]. Novoye literaturnoye obozreniye, № 60 Mocsow (2003), pp. 17-29.

9. M. Lind. Why mediate art? Ten fundamental question of Quration. Issue \#4: Is printed in Italy and published five times an year by Mousse Publishing. pp. 99-126. https://syg.ma/@uralskii-filial-gtssi/mariia-lind-zachiem-iskusstvu-miediatsiia (Accessed 31 August 2020)

10. J. Ortega y Gasset. Degumanizatsiya iskusstva [The Dehumanization of art]. Raduga, Moscow (1991). ISBN: 5-05-002557-5

11. A. Danto. The Artworld. The Journal of Philosophy. Vol. 61, No. 19 (1964), pp. 571-584. DOI: $10.2307 / 2022937$.

12. T. de Dyuv. Imenem iskusstva. K arkheologii sovremennosti [In the name of art. To the archaeology of modernity]. VSHE, Moscow (2014). ISBN 978-5-7598-1176-3.

13. V. Ben'yamin. Proizvedeniye iskusstva v epokhu yego tekhnicheskoy vosproizvodimosti [A work of art in the era of its technical reproducibility]. Medium, Moscow (1996).

14. A. Gyuyssen. Begstvo ot amnezii. Muzey kak massmedia. [Escape from amnesia. Museum as mass media] Iskusstvo, Moscow. № 2 (581) (2012). URL: https://iskusstvo-info.ru/begstvo-ot-amnezii-muzej-kak-massmedia/ (Accessed 31 August 2020)

15. N. Saymon. Partitsipatornyy muzey [Participatory Museum]. Marginem Press, Moscow (2017).

16. True needs. True partners: Museums and schools Transforming education. Institute of museum services, 1100 PennsylvaniaAve NW, Washington (1996).

17. B. Frankel. Diane True Needs True Partners. True needs. True partners. Museums and schools transforming education. Institute of museum services, NW, Washington, DC 20506 21. pp. 9-14. 
18. Time for Cultural Mediation. Ed. by C. Mörsch, S. Fürstenberg, A. Chrusciel. Institute for Art Education of Zurich University of the Arts (ZHdK), commissioned by Pro Helvetia (2013). URL: https://www.kultur-vermittlung.ch/zeit-fuer-vermittlung/v1/?m=0\&m2=1\&lang=e (Accessed 31 August 2020)

19. D. N. Malikova. Mediatsiya: kontseptsiya i opyt UIBSI. [Mediation: the concept and experience of UIBSI]. Ekonomika vpechatleniy: muzeynyy, sobytiynyy, turisticheskiy menedzhment. Perm', 14-15 marta 2019. Sbornik trudov konferentsii [Economy of impressions: Museum, event, and tourism management. Perm, March 14-15, 2019. Collection of the articles from the conference.] (2019), pp. 47-52.

20. D. N. Malikova. Metody raboty s auditoriyey khudozhestvennogo muzeya: ot traditsionnykh obrazovatel'nykh praktik $\mathrm{k}$ mediatsii. (Osmysleniye i integratsiya opyta Yevropeyskoy biyennale sovremennogo iskusstva "Manifesta 10"). Magisterskaya dissertatsiya [Methods of working with the audience of the art Museum: from traditional educational practices to mediation. (Understanding and integrating the experience of the European Biennale of contemporary art "Manifesta 10"). Master's thesis]. Ekaterinburg (2015).

21. N. V. Iyevleva, M. V. Potapova. Svobodnaya diskussiya: kak govorit's molodezh'yu v muzeye. [Free discussion: how to talk to young people in a Museum.] Muzey: nauchno-prakticheskiy zhurnal.[Museum: scientific and practical journal] Prosveshcheniye, Moscow. № 1-2. (2018), pp. 78-81.

22. D. Dzhoslit. Posle iskusstva [Joslit D. After the art.]. V-A-C press, Moscow (2017) https://artguide.com/posts/1199 (Accessed 31 August 2020)

23. E. Kochukhova. Transformation of Museum Communication through: The case of the 4-th Ural Industrial Biennial of Contemporary Art. Changing Societies \& Personalities. Vol. 3, No. 3 (2019), pp. 258-272.

24. A. Bulatova, N. Zhuravleva, S. Melnikova. The Significance of Art Mediation in Bridging the Communication Gaps. Fourth International Scientific Conference Communication Trends in the Post-literacy Era: multilingualism, multimodality, multiculturalism, Volume $2020 \mathrm{KnE}$ Social Sciences, pp. 1-13. DOI 10.18502/31

25. A.S. Housen. Aesthetic Thought, Critical Thinking and Transfer. Arts and Learning Research Journal, Vol. 18, No. 1 (2001-2002). op. 99-131

26. Visual Thinking Strategies URL: https://vtshome.org/ (Accessed 31 August 2020)

27. Rabota so studencheskoy auditoriyey $\mathrm{v}$ khudozhestvennom muzeye po metodike svobodnoy (fasilitirovannoy) diskussii. metodicheskoye posobiye. Sost. I. V. Iyevleva, M. V. Potapova [Work with the student audience in the art Museum 
using the method of free (facilitated) discussion. methodological guide. Comp. I. V. Ievleva, M. V. Potapova]. Polytechnic University, Saint Petersburg (2016).

28. Muzey i shkola v obrazovatel'nom prostranstve. Vypusk 2: "Obraz i mysl". Sb. Statey [Museum and school in the educational space. Issue 2: "Image and thought" Collection of articles]. Saint Petersburg (1997).

DOI 10.15826/B978-5-7996-3081-2.52

\title{
Multimedia Practices in Corporate Museums: Tribute to Fashion or Canon Transformation
}

\section{Pryamikova Elena ${ }^{1}$, Vandyshev Mikhail ${ }^{2}$}

1 Ural State Pedagogical University, Ekaterinburg, Russian Federation

${ }^{2}$ Ural Federal University, Ekaterinburg, Russian Federation

Corresponding author: Pryamikova Elena, pryamikova@yandex.ru

\begin{abstract}
In the framework of the project "Scaling social memory of generations in 'historically' and 'newly' industrialized cities" we have studied various organizations associated with commemoration work. We have interviewed people and have had excursions in various museums: school museums, town museums, local history museums, and corporate museums. All in all, we have visited 11 corporate museums in several cities of Ural region. Certainly, now the best equipped museums are corporate museums of economically booming plants. They are supplied with state-of-the-art equipment that allows them to create fundamentally new expositions, change the traditional canon of the exhibition and storage of museum collections. Nevertheless, not all corporate museums follow this route, there are some which maintain traditional practices of housing exhibits. How do corporate museums of towns and cities of the Ural region work today? How would museum staff like to change their work with regard to use of multimedia technologies?
\end{abstract}

Keywords: corporate museums, identity, multimedia equipment, multimedia practices, Ural region 